\title{
Nutrition care for chronic kidney disease during pregnancy: an updated review
}

\author{
María Angélica Reyes-López ${ }^{1} \cdot$ Giorgina B Piccoli $^{2}$ - Filomena Leone ${ }^{3} \cdot$ Alejandra Orozco-Guillén $^{4}$ • \\ Otilia Perichart-Perera (i] ${ }^{1}$
}

Received: 18 June 2019 / Revised: 5 December 2019 / Accepted: 18 December 2019 / Published online: 10 January 2020

(c) The Author(s) 2020. This article is published with open access

\begin{abstract}
Cases of chronic kidney disease (CKD), including CKD in pregnant women, have increased globally in recent years. CKD during pregnancy is associated with a higher risk of adverse outcomes, including gestational hypertension, preeclampsia, intrauterine growth restriction, and preterm birth, among others. Nutrition plays a significant role in many metabolic and physiological changes during pregnancy. Women with CKD are at increased risk of nutrition deficiencies and metabolic issues than women without CKD. Currently, we lack evidence regarding metabolic and nutritional adaptations during pregnancy in women with CKD and how these adaptations relate to perinatal outcomes. In this review, dietary and supplementation recommendations for CKD in adults and pregnant women are summarized from current clinical guidelines. We present the main nutrition care practices that have been studied in CKD pregnancies. This review will be helpful to health professionals as a preliminary reference for nutrition assessment and therapy in pregnant women with CKD.
\end{abstract}

\section{Introduction}

The frequency of chronic kidney disease (CKD) during pregnancy has increased. This could be related to the higher prevalence in CKD reported in recent years, the improvement of medical treatment in CKD adults, and a better kidney function assessment during pregnancy [1-3].

Pregnant women with CKD have specific nutritional needs and are at higher risk of adverse perinatal outcomes. There are currently no established guidelines to address nutrition therapy in this group. In this review, we aim to summarize established nutritional recommendations for nonpregnant individuals with CKD [4-6] and those for

Otilia Perichart-Perera

otiliaperichart@inper.gob.mx

1 Department of Nutrition and Bioprogramming, Instituto Nacional de Perinatología, Mexico City, Mexico

2 Department of Clinical and Biological Sciencies, The University of Torino, Turin, Italy

3 Hospital Cittá della Salute e della Scienza, Turin, Italy

4 Department of Critical Medicine, Instituto Nacional de Perinatología, Mexico City, Mexico healthy pregnant women [7-9], and present data from studies done in pregnant women with CKD.

\section{Nutrition intervention for pregnant women with CKD}

Nutrition therapy goals for pregnant women with CKD include to meet energy and nutrient needs for optimal fetal growth and development while promoting adequate metabolic control; to make individual recommendations for vitamin and mineral supplementation; and to promote a healthy lifestyle to improve maternal and fetal health.

\section{Energy and macronutrient recommendations in pregnant women with CKD}

\section{Energy recommendations}

CKD Resting energy expenditure (REE) appears to be higher in adults with CKD due to renal replacement therapy, poorly controlled diabetes mellitus (DM), severe hyperparathyroidism (HPT), and inflammation. In nondialyzed patients, REE tends to be equal or even lower than that of healthy individuals [10].

In stages 3-4 of CKD, the recommended energy intake is $96.2-146.4 \mathrm{~kJ} / \mathrm{kg} / \mathrm{day}$ (23-35 kcal/kg/day) using current 
weight [5]. During dialysis, American guidelines suggest to use $125.5-167.4 \mathrm{~kJ} / \mathrm{kg} /$ day (30-35 kcal/kg/day), while European guidelines recommend $125.5-167.4 \mathrm{~kJ} /$ per ideal body weight/day (30-40 kcal/kg/day) [5, 6].

CKD and pregnancy To estimate energy requirements in pregnant women, energy prediction equations can be used with pregestational weight, adding pregnancy energy needs $(355.6 \mathrm{~kJ} /$ day or $85 \mathrm{kcal} /$ day, $1192.4 \mathrm{~kJ} /$ day or $285 \mathrm{kcal} / \mathrm{day}$, and $1987.4 \mathrm{~kJ} /$ day or $475 \mathrm{kcal} /$ day during the $1 \mathrm{st}$, 2nd, and 3rd trimester, respectively) [8, 7].

Gestational weight gain is an important indicator of energy balance and should be monitored. In healthy pregnancy, weight gain is determined by the pregestational body mass index. Institute of Medicine's gestational weight gain recommendations range from $5 \mathrm{~kg}$ (in obesity) to $18 \mathrm{~kg}$ (in underweight). The Intergrowth Consortium suggests a gestational weight gain of $13.6 \mathrm{~kg}$ in normalweight women $[11,12]$.

In women with advanced CKD stages, weight gain assessment is a challenge. Data from dialysis patients have reported a weight gain of $1-1.5 \mathrm{~kg}$ during the first trimester and $0.5 \mathrm{~kg} / \mathrm{week}$ in the second and third trimesters [13]. Several reports of pregnant women undergoing dialysis with optimal perinatal outcomes showed a total weight gain between 5.2 and $12 \mathrm{~kg}$, with the highest gain in patients who received nutrition therapy [14-16].

In CKD pregnant women in stages 1 and 2, it seems prudent to use energy intake recommendations for healthy pregnant women. During stages 3 and 4, energy recommendations for nonpregnant CKD adults could be used, using pregestational weight and adding the energy cost of pregnancy. If pregestational weight is not reliable, current dry weight can be used without adding pregnancy requirements. For pregnant women under $\mathrm{HD}$ and peritoneal dialysis (PD), the Italian study group suggests $146.4 \mathrm{~kJ} / \mathrm{kg}(35 \mathrm{kcal} / \mathrm{kg}$ ) and $104.6 \mathrm{~kJ} / \mathrm{kg}$ $(25 \mathrm{kcal} / \mathrm{kg}$ ) with pregestational weight, respectively, and adding the energy cost of pregnancy [17]. Reported cases of pregnancies undergoing $\mathrm{HD}$ showed that an intake of $125.5-146.4 \mathrm{~kJ} /$ pregestational $\quad(30-35 \mathrm{kcal} / \mathrm{kg}) \quad$ plus $1255.2-1674.4 \mathrm{~kJ}$ (300-400 kcal/day) from the second trimester was positively associated with maternal weight gain, lower incidence of small-for-gestational age (SGA), and less frequent neonatal intensive care unit hospitalization [14-16, 18, 19].

\section{Protein recommendations}

CKD For adults with CKD with a glomerular filtration rate (GFR) below $50 \mathrm{ml} / \mathrm{min}$ per $1.73 \mathrm{~m}^{2}$, the protein intake recommendation is $0.6-0.8 \mathrm{~g} / \mathrm{kg} / \mathrm{day}$. When GFR is $<20 \mathrm{ml} / \mathrm{min}$ per $1.73 \mathrm{~m}^{2}$, a very low-protein diet may be prescribed $(0.3-0.5 \mathrm{~g} / \mathrm{kg} /$ day $)$ with ketoacid analog supplementation [5].
In adults under dialysis, protein intake recommendations range from 1.1 to $1.3 \mathrm{~g} / \mathrm{kg} / \mathrm{day}$, using ideal or current dry body weight. Protein intake should be increased with more intensive HD [6]. At least 50\% of dietary protein should be of high biological value $[4,6]$.

Signs, symptoms, and markers related to uremic syndrome and renal function (GFR, BUN, serum creatinine, and proteinuria) should be monitored to individualize protein intake recommendations.

CKD and pregnancy Protein requirements in pregnancy are $71 \mathrm{~g} / \mathrm{day}$ or $1.1 \mathrm{~g} / \mathrm{kg} / \mathrm{day}$. Adult protein requirements can be used $(0.8 \mathrm{~g} / \mathrm{kg}$ of pregestational weight/day) if additional protein needs of pregnancy are added $(+1,9$, and $31 \mathrm{~g} /$ day during the 1st, 2nd, and 3rd trimester, respectively) [7, 9].

For pregnant women in CKD stages 1 and 2, recommended protein intake may be similar to that for a healthy pregnancy. In advanced CKD stages and under dialysis, protein recommendations for adults with CKD may be used, while adding the extra needs of pregnancy. In stages $3-5$, a moderate-protein-restricted plant-based diet $(0.6-0.8 \mathrm{~g} / \mathrm{kg} /$ day of protein) plus keto-analogs ( 1 tablet $/ 8-10 \mathrm{~kg}$ ) showed a lower frequency of early preterm delivery, very low birth weight (LBW) $(<1500 \mathrm{~g})$ and SGA infants [20-23]. In different reported case series of pregnant women under HD, a protein intake of $1.2-1.5 \mathrm{~g} / \mathrm{kg}$ of ideal body weight/day plus 6-10 g/day was related with optimal plasmatic nitrogen compounds levels, controlled blood pressure, reduced proteinuria, and improved plasmatic albumin and phosphorus $[14,15,18]$. Vidal et al. observed an optimal maternal weight gain, good calcium-phosphate metabolism, and favorable neonatal outcomes with $1.1-1.2 \mathrm{~g} / \mathrm{kg} /$ day (pregestational dry weight/day) of protein during the first trimester and $1.5 \mathrm{~g} / \mathrm{kg}$ (current body weight) in the second and third trimesters [16]. Espinoza et al. recommended a higher amount of protein $(1.8-2 \mathrm{~g} / \mathrm{kg} /$ day) and added intradialytic amino acids in cases of low intake, observing a lower incidence of SGA infants [19]. According to the Italian study group, protein intake recommendations for $\mathrm{HD}$ and $\mathrm{PD}$ should be 1.2 and $1.4 \mathrm{~g} / \mathrm{kg} /$ day pregestational weight, respectively [17].

\section{Lipid recommendations}

CKD CKD is associated with dyslipidemia, showing similar characteristics in early and advanced kidney failure [low high-density lipoproteins, normal or low total cholesterol, high low-density lipoprotein cholesterol and increased triglycerides (TG)]. Lipid profile in patients with PD tends to be more atherogenic [24, 25].

Lipid and saturated fat intakes for individuals with CKD should be maintained below 30 and $10 \%$ of total energy intake (TEI), respectively [25]. In hypertriglyceridemia, a low-fat diet $(<15 \%$ TEI) is suggested with an accompanying 
reduction in mono and disaccharide intake and the use of fish oil to replace long-chain TGs [25]. In case of hypercholesterolemia, monounsaturated fat recommended intake is $>10 \%$, saturated fatty acid $<10 \%$, and cholesterol intake $<300 \mathrm{mg} /$ day [6].

CKD and pregnancy Lipid metabolism during pregnancy is characterized by an accumulation of fat in maternal depots during early pregnancy and the later development of hyperlipidemia due to increasing lipolysis and mobilization of TG [26].

No lipid status has been reported in CKD pregnant women. In our case series of pregnant women with CKD (without dialysis), mean serum cholesterol and TG were $246.6 \pm 116.7 \mathrm{mg} / \mathrm{dL}$ and $277.0 \pm 187.0 \mathrm{mg} / \mathrm{dL}$, respectively, in the second trimester, and $277.1 \pm 129.3 \mathrm{mg} / \mathrm{dL}$ and $341.1 \pm 190.6 \mathrm{mg} / \mathrm{dL}$, respectively, in the third trimester $(n=48)$ (unpublished data).

The total fat intake recommendation in pregnancy is $<30-35 \%$ of TEI [7]. Omega 3 fatty acids play an important role in retinal and neurological fetal development. European recommendations for EPA + DHA are $250 \mathrm{mg} / \mathrm{day}$ and an extra 100-200 mg/day of DHA [27]. Linoleic and $\alpha$ linolenic fatty acids intake recommendations are $13 \mathrm{~g} /$ day and $1.4 \mathrm{~g} /$ day, respectively $[7,27,28]$. Oily fish (salmon, trout, sardines, and tuna) consumption should be increased during pregnancy $(250-300 \mathrm{~g} /$ week $)[7,8]$.

\section{Carbohydrate recommendations}

Glucose metabolism is frequently impaired in CKD due to reduced insulin-mediated glucose uptake in skeletal muscle. Insulin resistance is more frequent in advanced CKD stages. Although some patients can compensate for insulin resistance by increasing insulin secretion, defects in insulin secretion are common [29].

In adults with CKD and DM, carbohydrate intake recommendations should be addressed to manage hyperglycemia, aiming to achieve glycemic control (HbA1C $<7 \%)$ [5].

Early pregnancy is characterized by an increase in insulin sensitivity, while an insulin resistance state develops during late pregnancy to prioritize the use of fats for energy, sparing carbohydrates for the fetus [30]. If CKD pregnant women have previous DM or GDM, glycemic control is the main goal of treatment (goal:fasting capillary glucose $\leq 95 \mathrm{mg} / \mathrm{dL}$ and 1-h postprandial capillary glucose $\leq 140 \mathrm{mg} / \mathrm{dL}$ ) [31].

In a healthy pregnancy, acceptable carbohydrate recommended intake is $45-65 \%$ of TEI [28], while fiber intake recommendation is $28 \mathrm{~g} /$ day [28]. In women with previous DM or GDM, carbohydrate recommendations should be individualized [31]. The most accepted strategies include monitoring carbohydrate intake ('carb counting').
Three meals and 2-3 snacks are preferred while promoting healthy carbohydrate consumption (low-glycemic index foods and/or high-fiber food sources) and avoiding added sugars and processed foods [32, 33]. A minimal carbohydrate intake of $175 \mathrm{~g} /$ day during pregnancy seems appropriate [28].

\section{Fluids}

CKD is associated with hydroelectrolytic disturbances. When GFR is below $20 \mathrm{~mL} / \mathrm{min}$, the kidney loses its capacity to concentrate or dilute the urine [34]. Sodium and water recommendations should be individualized based on diuresis and interdialytic weight gain in dialysis patients. Interdialytic weight gain has been suggested to be $4-4.5 \%$ of dry weight [5]. Fluid intake recommendation for a healthy pregnancy is 3 L/day [28]. Table 1 summarizes energy and macronutrient recommendations for pregnant women with CKD.

\section{Vitamin and mineral recommendations}

In early CKD stages, micronutrient intake recommendations are similar to those for a healthy pregnancy. Specific recommendations are now needed for those at more advanced stages of CKD and pregnant women on dialysis. Table 2 summarizes vitamin and mineral recommendations for healthy pregnant women and for nonpregnant CKD individuals.

\section{Calcium, vitamin $\mathrm{D}$, and phosphorus}

CKD CKD is characterized by disturbances in mineral, vitamin $\mathrm{D}$, and parathyroid hormone (PTH) metabolism [35]. As GFR declines, a fall in the activity of the renal vitamin $\mathrm{D} 1 \alpha$-hydroxylase enzyme is observed. As a result, the conversion of vitamin $\mathrm{D}$ to its active form, 25hydroxyvitamin D (25-OH-D), is impaired. Consequently, vitamin D-dependent calcium absorption is limited, hypocalcemia occurs, and PTH production increases in a counterregulatory attempt to release calcium from bone stores. In contrast, phosphorus excretion is decreased, triggering an increased production of fibroblast growth factor, which also suppresses $1 \alpha$-hydroxylase. The release of bone mineral stores exacerbates hyperphosphatemia, which promotes further production of PTH $[35,36]$.

KDIGO recommends measuring serum 25-OH-D, calcium, phosphorus, PTH, and alkaline phosphatase activity at least once in adults with CKD stage 3 and above, and then annual reassessment if levels are within normal parameters [3]. Clinical signs and symptoms of hyperphosphatemia (Itching, bone pain, and vascular calcification) related to the advanced stages of CKD should be assessed and monitored [36]. 
Table 1 Macronutrient recommendations for CKD pregnant women.

\begin{tabular}{llll}
\hline & Trimester & CKD stages & \\
\cline { 3 - 4 } & & CKD 3-5 stages & Dialysis \\
\hline${\text { Energy }(\mathrm{kJ} / \mathrm{kg} / \mathrm{day})^{\mathrm{a}}}$ & First & $96-146+289 \mathrm{~kJ}$ & $105-146+289 \mathrm{~kJ}^{\mathrm{b}}$ \\
& Second & $96-146+1100-1423 \mathrm{~kJ}$ & $105-146+1100-1423 \mathrm{~kJ}^{\mathrm{b}}$ \\
& Third & $96-146+1891-2096 \mathrm{~kJ}$ & $105-146+1891-2096 \mathrm{~kJ}^{\mathrm{b}}$ \\
& First & $0.6-1.0+0.7 \mathrm{~g}$ & $1.1-1.5+0.7 \mathrm{~g}$ \\
Protein $(\mathrm{g} / \mathrm{kg} /$ day) & Second & $0.6-1.0+9.6 \mathrm{~g}$ & $1.1-1.5+9.6 \mathrm{~g}$ \\
& Third & $0.6-1.0+31.2 \mathrm{~g}$ & $1.1-1.5+31.2 \mathrm{~g}$ \\
Carbohydrates \% TEI & & $35-65$ & \\
Fiber (g/day) & & $20-30$ & \\
Lipids \% TEI & & $\leq 30$ & \\
Saturated fatty acids \% TEI & & $<7-10^{\mathrm{c}}$ & \\
Monounsaturated fatty acids \% TEI & & $10-20^{\mathrm{d}}$ & \\
Polyunsaturated fat \% TEI & & $\leq 10$ & \\
Linoleic acid (g/day) & & 13 & \\
$\alpha$-Linolenic acid (g/day) & & 1.4 & \\
DHA (mg/day) & & 200 & \\
Cholesterol (mg/day) & $<200-300$ & \\
\hline
\end{tabular}

${ }^{a}$ Pregestational body weight

${ }^{b}$ Due glucose absorption from dialysate, the lower range is suggested for peritoneal dialysis

${ }^{\mathrm{c}}$ In case of dialysis apply $7 \%$ of TEI

${ }^{\mathrm{d}}$ In case of dialysis apply $20 \%$ of TEI. From references [4-9, 27, 28]
During stages 3-5 and HD, the Academy of Nutrition and Dietetics suggests a total elemental calcium intake (from the diet, supplements, and phosphate binders) $<2$ g/day in CKD patients [5].

Dietary phosphorus should be restricted to $800-1000 \mathrm{mg} /$ day when serum phosphorus levels are $>4.6 \mathrm{mg} / \mathrm{dL}$ (stages 3-4) or $>5.5 \mathrm{mg} / \mathrm{dL}$ (stage 5) [5]. Dietary phosphorus restriction is also needed when plasma PTH is $>70 \mathrm{pg} / \mathrm{ml}$ in more than two consecutive measurements. Dietary strategies for phosphorus restriction include to avoid organic (i.e., dairy, meats, poultry, fish, and grains) and inorganic (preservatives and additives) sources [36].

Vitamin D supplementation with 800-1000 IU of cholecalciferol is indicated when serum 25-OH-D is below $30 \mathrm{ng} / \mathrm{ml}$ or in stages $4-5$ with severe and progressive HPT [36].

In stages 3-4, active oral supplementation with calcitriol or vitamin D analogs is indicated when plasma PTH is high and in patients with serum corrected total calcium $<9.5 \mathrm{mg}$ / $\mathrm{dL}$ and serum phosphorus $<4.6 \mathrm{mg} / \mathrm{dL}$ [5].

CKD and pregnancy During a healthy pregnancy, calcium absorption is stimulated to meet increased requirements [37]. Increased production of $1,25[\mathrm{OH}]_{2} \mathrm{D}$ secondary to 1-alpha-hydroxylase placental activity is observed. Vitamin D homeostasis is characterized by an increase in maternal calcitriol, enhanced availability of maternal 25-OH-D, and increase of maternal vitamin D-binding protein concentrations [37]. The American College of Obstetricians and Gynecologists considers levels of circulating 25-OH-D below $32 \mathrm{ng} / \mathrm{mL}$ during pregnancy as deficient [38].

There are no reports of serum PTH and 25-OH-D concentrations in CKD pregnant women. In our case series of pregnant women with CKD (stages 1-4 without dialysis), we observed PTH levels in the second and third trimesters of $55.3 \pm 107.6 \mathrm{pg} / \mathrm{ml}$ and $47.7 \pm 36.9 \mathrm{pg} / \mathrm{ml}$, respectively. These concentrations exceed normal ranges for a healthy pregnancy but are within normal ranges reported in CKD adults (Table 3). Plasma 25-OH-D concentrations were $27.6 \pm 11.7 \mathrm{ng} / \mathrm{ml}$ (second trimester) and $28.5 \pm 10.7 \mathrm{ng} / \mathrm{ml}$ (third trimester). During the second and third trimesters, $22 \%(n=8 / 36)$ and $19 \%(n=5 / 26)$ of women had low $25-\mathrm{OH}-\mathrm{D}(<20 \mathrm{ng} / \mathrm{mL})$, respectively. We observed a positive correlation between PTH net change from the second to the third trimester with plasma phosphorus concentration in the third trimester $(r=0.43$, $p=0.020$ ) (unpublished data). Table 3 shows the reference values for bone mineral metabolism biochemical markers in CKD and during healthy pregnancy.

In healthy pregnant women with adequate vitamin $\mathrm{D}$ stores and normal PTH levels, calcium intake should be $1000-1300 \mathrm{mg} / \mathrm{day}$ [27, 39]. The WHO recommends $1.5-2.0 \mathrm{~g} /$ day of elemental calcium in women with a high risk of developing preeclampsia (i.e., CKD) and with low- 
Table 2 DRI and DRV of micronutrients for healthy pregnant women over 18 years and for nonpregnant CKD individuals.

\begin{tabular}{|c|c|c|c|}
\hline \multirow[t]{2}{*}{ Nutrient } & \multirow{2}{*}{$\begin{array}{l}\text { Pregnancy } \\
\text { Healthy pregnancy } \\
\left(_{\text {DRI-DRV) }}^{\text {a }}\right.\end{array}$} & \multicolumn{2}{|c|}{ Nonpregnant CKD individuals } \\
\hline & & Pre-ESRD & Dialysis \\
\hline Calcium (mg) & $950-1000$ & $<2000$ & $<1500-2000$ \\
\hline Phosphorus (mg) & $550-700$ & $800-1000$ & $800-1000$ \\
\hline Potassium (mg) & $3500-4700$ & $\leq 2400$ & $3700-5200$ \\
\hline Sodium (mg) & 1500 & $<2400$ & $2000-2300$ \\
\hline Iron $(\mathrm{mg})$ & $16-27$ & $15^{\mathrm{c}}$ & $15^{\mathrm{c}}$ \\
\hline Zinc (mg) & $11-12^{\mathrm{d}}$ & $8-12$ & $8-12$ \\
\hline Magnesium (mg) & $300-350$ & $290-300$ & $200-300$ \\
\hline Vitamin D (UI) & 600 & $800-1000$ & $800-1000^{\mathrm{f}}$ \\
\hline Vitamin A $(\mu \mathrm{g})$ & $700-770$ & 550 & $700-900$ \\
\hline Vitamin C (mg) & $85-105$ & $30-60$ & $75-90$ \\
\hline Vitamin B1 (mg) & $0.8-1.4^{\mathrm{g}}$ & 1.1 & $1.1-1.2$ \\
\hline Vitamin B2 (mg) & $1.4-1.9$ & 1.1 & $1.1-1.3$ \\
\hline Vitamin B3 (mg) & $13.4-18^{\mathrm{g}}$ & 14 & $14-16$ \\
\hline Vitamin B6 (mg) & $1.8-1.9$ & 5 & 10 \\
\hline Vitamin B12 $(\mu \mathrm{g})$ & $2.2-4.5$ & $>2-3$ & 2.4 \\
\hline Biotin $(\mu \mathrm{g})$ & $30-40$ & $30-100$ & 30 \\
\hline Folic acid (mg) & 0.6 & $>1$ & 1.0 \\
\hline
\end{tabular}

$D R I$ dietary references intakes, $D R V$ dietary references values, $E S R D$ end-stage-renal disease

${ }^{\mathrm{a}}$ Recommended dietary allowance (RDA) and Populations reference intake (PRI)

${ }^{\mathrm{b}}$ Pregestational body weight

${ }^{c}$ According iron studies and erythropoiesis-stimulating agent use

${ }^{\mathrm{d}}$ Based on the average for zinc recommendation according phytates consumption and the amount add for pregnancy

${ }^{\mathrm{e}} 1,25(\mathrm{OH}) 2 \mathrm{D} 3$ if low serum levels

${ }^{\mathrm{f}}$ Adjust dose based on phosphorus, calcium, PTH levels

${ }^{\mathrm{g}}$ For each $2000 \mathrm{kcal}$. From refs. [4, 5, 27, 28] calcium intakes [40]. Phosphorus intake recommendation for healthy pregnancy is $700-1250 \mathrm{mg} /$ day $[27,39]$. High prevalence of low serum 25-OH-D are frequently reported during pregnancy, so 25-OH-D assessment seems important to decide if supplementation is necessary [37]. Vitamin D doses of 1000-2000 IU/day as supplements could be considered safe during pregnancy [38].

Calcium supplementation has been reported in isolated case studies, ranging from 300 to $1500 \mathrm{mg} /$ day $[14,16]$.

Due to more frequent dialysis sessions, phosphorus restriction, and phosphate binders use might not be needed in CKD pregnancies [2]. Although oral vitamin D supplementation is suggested in CKD pregnant women, very low doses have been used (10-250 UI/day) $[14,16]$. Vitamin D analogs have been given intravenously to pregnant women undergoing dialysis, but it is not clear whether they have any adverse effect on the fetus. Once 25$\mathrm{OH}-\mathrm{D}$ reaches its optimal levels, a vitamin D-containing multivitamin should be continued [41].

\section{Iron, folic acid, and cobalamin}

CKD Anemia in women with CKD is diagnosed when hemoglobin levels are below $12.0 \mathrm{~g} / \mathrm{dL}$, and it is associated with insufficient production and release of erythropoietin (EPO), so in most cases, anemia is characterized as being hyperproliferative, normochromic, and normocytic [42]. Besides insufficient EPO production, iron deficiency is the most common reversible cause of chronic anemia in CKD patients. An in-depth assessment that includes a complete blood count, absolute reticulocyte count, serum ferritin level, serum transferrin saturation (TSAT), serum vitamin B12, and folate levels should be performed [42]. KDIGO suggests monitoring nonanemic CKD patients when clinically indicated or annually (stage 3 ), twice per year (stages 4-5 without dialysis), or every 3 months (stage 5 with dialysis). Iron status should be monitored every 3 months with more frequent assessments in individuals on HD and receiving erythropoiesis-stimulating agents (ESA) [43]. 
Table 3 Reference values for biochemical markers assessment in CKD and in pregnancy.

\begin{tabular}{|c|c|c|c|c|}
\hline & \multirow[t]{2}{*}{ Women with CKD } & \multicolumn{3}{|c|}{ Pregnancy without CKD } \\
\hline & & $\begin{array}{l}\text { First } \\
\text { trimester }\end{array}$ & $\begin{array}{l}\text { Second } \\
\text { trimester }\end{array}$ & $\begin{array}{l}\text { Third } \\
\text { trimester }\end{array}$ \\
\hline \multicolumn{5}{|l|}{ Bone mineral metabolism } \\
\hline Calcium (mg/dL) & $9-10.5$ & $8.8-10.6$ & $8.2-9.0$ & $8.2-9.7$ \\
\hline Phosphorus (mg/dL) & $3-4.5$ & $3.1-4.6$ & $2.5-4.6$ & $2.8-4.6$ \\
\hline $\begin{array}{l}\text { Vitamin D } \\
25 \text { hydroxycholecalciferol (pg/mL) }\end{array}$ & $30-65$ & $20-65$ & $72-160$ & $60-119$ \\
\hline Parathyroid hormone $(\mathrm{pg} / \mathrm{mL})$ & $\begin{array}{l}\text { Stage 3: } 35-70 \\
\text { Stage 4: } 70-110 \\
\text { Stage } 5 \text { and } \\
\text { dialysis: } 150-300\end{array}$ & $10-15$ & $18-25$ & $9-26$ \\
\hline Alkaline phosphatase (IU/L) & $30-85$ & $17-88$ & $25-126$ & $38-229$ \\
\hline \multicolumn{5}{|l|}{ Iron status } \\
\hline Hemoglobin (g/dL) & $11-12$ & $\geq 11.0$ & $\geq 10.5$ & $\geq 11.0$ \\
\hline Hematocrit (\%) & $37-47$ & $\geq 33$ & $\geq 32$ & $\geq 33$ \\
\hline Serum iron $(\mu \mathrm{g} / \mathrm{dL})$ & $50-170$ & $72-143$ & $44-178$ & $30-193$ \\
\hline Ferritin $(\mathrm{ng} / \mathrm{mL})$ & $\begin{array}{l}\text { Not dialysis }>30 \\
\mathrm{HD} \geq 20-\mathrm{PD}>100\end{array}$ & $6-130$ & $2-230$ & $0-116$ \\
\hline $\begin{array}{l}\text { Total iron binding capacity (TICB) } \\
(\mu \mathrm{g} / \mathrm{dL})\end{array}$ & $250-420$ & $278-403$ & - & $359-609$ \\
\hline Transferrin saturation $(\%)^{\mathrm{a}}$ & $\geq 20$ & Not reported & $18-92$ & 9-98 \\
\hline
\end{tabular}

$H D$ hemodialysis, $P D$ peritoneal dialysis

${ }^{a}$ Measure when clinically stable, not measure in acute illness. Pregnancy references adapted from: AbbassiGhanavati, Greer, Cunningham. Pregnancy and Laboratory Studies. Obstet Gynecol. 2009;114:(6)1326-31. From refs. [36, 42]

KDIGO recommends IV or oral iron trials in adults with or without ESA therapy if the goal is to increase $\mathrm{Hb}$ without starting ESA treatment, or to decrease ESA dose, and if transferrin saturation is $<30 \%$ and ferritin are $<500 \mathrm{ng} / \mathrm{ml}$ [42]. For HD individuals, the recommendation is $50-60 \mathrm{mg}$ of intravenous iron per week [43]. Cobalamin and folic acid supplementation are recommended if the mean corpuscular volume is $>100 \mathrm{ng} / \mathrm{ml}$ and if serum levels of these nutrients are below normal values [5].

CKD and pregnancy The World Health Organization (WHO) defines anemia during pregnancy as $\mathrm{Hb}<11 \mathrm{~g} / \mathrm{dL}$ or hematocrit $<33 \%$ at any time during the pregnancy [44]. Physiologic anemia of pregnancy reflects an expansion of plasma volume of $50 \%$. Globally, the most common cause for anemia of pregnancy is iron deficiency and is related to increased iron requirements. Iron-deficiency anemia is associated with higher rates of preterm birth, LBW, and SGA newborns [44].

Inadequate intake of folic acid is associated with a higher risk of neural tube defects, LBW, and SGA. Maternal vitamin B12 status affects fetal growth and development, and its low levels are associated with some metabolic alterations and impaired neurodevelopment [44]. In CKD pregnant women, anemia might also be related to a higher risk of prematurity, LBW, and adverse perinatal outcomes
[1]. Table 3 shows the reference values for iron status markers in $\mathrm{CKD}$ and during a healthy pregnancy.

The WHO recommends supplementing 30-60 mg/day of elemental iron daily and $400 \mu \mathrm{g} /$ day of folic acid starting 3 months before pregnancy. In the case of anemia, $120 \mathrm{mg} /$ day of oral iron is recommended [45, 46]. Iron IV supplementation is considered when oral iron intolerance is reported in severe anemia $(<8 \mathrm{~g} / \mathrm{dL})$ [44]. Cobalamin supplementation is not routinely recommended except for vegetarian/vegan women or those with a very low intake of animal products [8].

Oral iron supplementation is safe in CKD pregnancies under HD. IV iron might be used in dialysis during pregnancy with caution. Cabiddu suggests to use 20-30 mg/day of IV elemental iron (iron gluconate) until transferrin saturation reaches $30 \%$ and serum ferritin 200-300 ng/mL [17]. Folic acid needs are higher in CKD pregnancies; supplementation has been recommended with doses ranging between 1 and $5 \mathrm{mg} /$ day, considering the higher doses for pregnant women receiving HD [2, 41].

\section{Sodium and potassium}

In CKD adults, sodium and potassium recommendations should be individualized based on serum concentrations, blood pressure, medications, hydration status, and kidney 
function. Clinical signs and symptoms of hyperkalemia (tremor, muscle weakness, dyspnea, bradycardia, arrhythmia, and nausea) should be assessed and monitored. In hyperkalemic adults with CKD, dietary intake of potassium $<2.4 \mathrm{~g} /$ day is recommended. Restriction of some fruits, vegetables, and other foods rich in potassium (processed foods with chemical potassium compounds) might be needed [5].

In CKD, sodium intake recommendation should be maintained at $<2.4 \mathrm{~g} /$ day by limiting the consumption of processed meats, smoked foods, ready-to-use seasonings and dressings, instant soups, preservatives, and salt additives [5].

In a group of pregnant women under HD $(18-24 \mathrm{~h} /$ week), Vidal et al. offered 3-4 g/day of salt and $3 \mathrm{~g}$ of potassium, among other recommendations, reporting positive perinatal outcomes [16].

\section{Conclusions}

Given the lack of specific research on this population, it is possible to make adaptations to the guidelines used for healthy pregnant and for nonpregnant individuals with $\mathrm{CKD}$. The role of the renal nutritionist is key in tailoring energy and nutrient intakes to promote maternal and fetal health and metabolic control. More research is urgently needed to develop nutritional guidelines for this population.

Acknowledgements We thank the undergraduate students for their effort in the nutrition care and follow-up of pregnant women with CKD. We thank the Research Direction of the Instituto Nacional de Perinatologia for the financial support for offering nutrition care to these women (project No. 212250-3310-11402-01-16).

Authors' contributions MAR was responsible for the literature search and drafting of the paper. As a clinical nutritionist, she critically reviewed the evidence according to her experience with this group of women at the Instituto Nacional de Perinatología. GBP contributed to writing the final version and is responsible for the nephrology and clinical sections. FL contributed to drafting the paper, particularly in regard to nutrition care. OAOG contributed to writing the first draft and gave her input as a nephrologist working on the medical care of pregnant women with CKD. OPP supervised the review process and was responsible for editing the final version of the paper.

\section{Compliance with ethical standards}

Conflict of interest OPP is a speaker for the Nestlé Nutrition Institute in Mexico. This paper contains no conflict of interest regarding this institution. The rest of the authors declare that they have no conflict of interests.

Publisher's note Springer Nature remains neutral with regard to jurisdictional claims in published maps and institutional affiliations.
Open Access This article is licensed under a Creative Commons Attribution 4.0 International License, which permits use, sharing, adaptation, distribution and reproduction in any medium or format, as long as you give appropriate credit to the original author(s) and the source, provide a link to the Creative Commons license, and indicate if changes were made. The images or other third party material in this article are included in the article's Creative Commons license, unless indicated otherwise in a credit line to the material. If material is not included in the article's Creative Commons license and your intended use is not permitted by statutory regulation or exceeds the permitted use, you will need to obtain permission directly from the copyright holder. To view a copy of this license, visit http://creativecommons. org/licenses/by/4.0/.

\section{References}

1. Winfield S, Davison JM. Pregnancy and chronic kidney disease. In: Mustafa Arici, editor. Management of chronic kidney disease: a clinician's guide. 1st ed. Berlin: Springer, Berlin, Heidelberg; 2014. p. 363-79.

2. Alkhunaizi A, Melamed N, Hladunewich MA. Pregnancy in advanced chronic kidney disease and end-stage renal disease. Curr Opin Nephrol Hyperten S. 2015;24:252-9.

3. KDIGO 2012. Official Journal of the International Society of Nephrology KDIGO 2012. Clinical practice guideline for the evaluation and management of chronic kidney disease. Kidney Int Suppl. 2013;3:1-150.

4. K/DOQI N. KDOQI nutrition in chronic renal failure. Am J Kidney Dis. 2000;35:1-141.

5. Academy of Nutrition and Dietetics. EAL. Chronic Kidney Disease (2010) Evidence-Based Nutrition Practice Guideline. U.S.: Academy of Nutrition and Dietetics; 2015.

6. Fouque D, Vennegoor M, Wee P Ter, Wanner C, Basci A, Canaud B, et al. EBPG guideline on nutrition. Nephrol Dial Transplant. 2007;22:45-87.

7. Hanson MA, Bardsley A, De-Regil LM, Moore SE, Oken E, Poston L, et al. The International Federation of Gynecology and Obstetrics (FIGO) recommendations on adolescent, preconception, and maternal nutrition: "Think Nutrition First". Int J Gynaecol Obstet. 2015;131:S213.

8. Procter SB, Campbell CG. Position of the academy of nutrition and dietetics: nutrition and lifestyle for a healthy pregnancy outcome. J Acad Nutr Diet. 2014;114:1099-103.

9. WHO/FAO/UNU. Protein and amino acids requirements in human nutrition. Report of a joint WHO/FAO/UNU Expert Consultation. U.S.: WHO/FAO/UNU; 2007.

10. Avesani CM, Kamimura MA, Cuppari L, Energy expenditure in chronic kidney disease patients. J Ren Nutr. 2011;21:27-30. https://linkinghub.elsevier.com/retrieve/pii/S1051227610002888.

11. Rasmussen KM, Yaktine Ann L. Weight gain during pregnancy: reexamining the guidelines. Vol. 1, Nutrition. National U.S.: Academies Press; 2009. p. 250.

12. Ismail LC, Bishop DC, Pang R, Ohuma EO, Kac G, Abrams B, et al. Gestational weight gain standards based on women enrolled in the Fetal Growth Longitudinal Study of the INTERGROWTH21st project: a prospective longitudinal cohort study. BMJ. 2016;352:1-10.

13. Furaz-Czerpak KR, Fernández-Juárez G, Ángeles Moreno-de la Higuera M, Puente-García A, Corchete-Prats E, Martín-Hernández R. Embarazo en mujeres en diálisis crónica: revisión. Nefrologia. 2012;32:287-94.

14. Campos-Collado AX, Reyes-López MA, Orozco-Guillén A, Muñoz-Manrique C, Perichart-Perera O. Medical nutrition therapy 
for chronic kidney disease in pregnancy: a case report. J Acad Nutr Diet. 2016;116:213-8.

15. Guida B, Pollio F, Nastasi A, Trio R, Laccetti R, Di Lieto A, et al. Nutritional intervention in a hemodialysis pregnant woman: a case report. Clin Nutr. 2003;22:205-7.

16. Vidal M, Ursu M, Martínez A, Sánchez R, Pereira D. Nutritional control of pregnant women on chronic hemodialysis. J Ren Nutr. 1998;8:150-6.

17. Cabiddu G, Castellino S, Gernone G, Santoro D, Moroni G, Giannattasio $\mathrm{M}$, et al. A best practice position statement on pregnancy in chronickidney disease: the Italian Study Group on Kidney and Pregnancy. J Nephrol. 2016;29:277-303.

18. Jagielski JB. Optimizing nutritional care for pregnant patients on hemodialysis. J Ren Nutr. 2015;25:e19-21.

19. Espinoza F, Romeo R, Ursu M, Tapia A, Vukusich A. Embarazos exitosos en hemodiálisis crónica: experiencia de un único centro T. Rev Med Chil. 2013;141:1003-9.

20. Attini R, Leone F, Parisi S, Fassio F, Capizzi I, Loi V, et al. Veganvegetarian low-protein supplemented diets in pregnant CKD patients: fifteen years of experience. BMC Nephrol. 2016;17:1-23.

21. Piccoli G, Leone F, Attini R, Parisi S, Fassio F, Deagostini M. Association of low-protein supplemented diets with fetal growth in pregnant women with CKD. Clin J Am Soc Nephrol. 2014;9:864-73.

22. Piccoli GB, Attini R, Vasario E, Gaglioti P, Piccoli E, Consiglio $\mathrm{V}$, et al. Vegetarian supplemented low-protein diets. A safe option for pregnant CKD patients: report of 12 pregnancies in 11 patients. Nephrol Dial Transplant. 2011;26:196-205.

23. Nava J, Moran S, Figueroa V, Salinas A, Lopez M, Urbina R, et al. Successful pregnancy in a CKD patient on a low-protein, supplemented diet: an opportunity to reflect on CKD and pregnancy in Mexico, an emerging country. J Nephrol. 2017;30:877-82.

24. Mikolasevic I, Žutelija M, Mavrinac V, Orlic L. Dyslipidemia in patients with chronic kidney disease: etiology and management. Int J Nephrol Renovasc Dis. 2017;10:35-45.

25. Willis K, Cheung M, Slifer S. Kidney Disease: Improving Global Outcomes (KDIGO) lipid work group. KDIGO clinical practice guideline for lipid management in chronic kidney disease. Kidney Int Suppl. 2013;3:259-305.

26. Herrera E, Ortega-Senovilla H. Lipid metabolism during pregnancy and its implications for fetal growth. Curr Pharm Biotechnol. 2014;15:24-31.

27. EFSA (European Food Safety Authority). Dietary reference values for nutrients summary report. EFSA Support Publ. 2017;14:1-98.

28. Food and Nutrition Board. Dietary reference intakes for energy, carbohydrate, fiber, fat, fatty acids, cholesterol, protein, and amino acids (macronutrients). Washington, D.C.: Food and Nutrition Board; 2005.

29. de Boer IH, Zelnick L, Afkarian M, Ayers E, Curtin L, Himmelfarb J, et al. Impaired glucose and insulin homeostasis in moderate-severe CKD. J Am Soc Nephrol. 2016;27:2861-71.

30. LAIN KY, CATALANO PM. Metabolic changes in pregnancy. Clin Obstet Gynecol. 2007;50:938-48.

31. American Diabetes Association AD. 14. Management of diabetes in pregnancy: standards of medical care in diabetes-2019. Diabetes Care. 2019;42:S165-72.
32. Hod M, Kapur A, Sacks DA, Hadar E, Agarwal M, Di Renzo GC, et al. The International Federation of Gynecology and Obstetrics (FIGO). Initiative on gestational diabetes mellitus: a pragmatic guide for diagnosis, management, and care. Int J Gynecol Obstet. 2015;131:S173-211.

33. Duarte-Gardea MO, Gonzales-Pacheco DM, Reader DM, Thomas AM, Wang SR, Gregory RP, et al. Academy of nutrition and dietetics gestational diabetes evidence-based nutrition practice guideline. J Acad Nutr Diet. 2018;118:1719-42.

34. Mazza Do Nascimiento, M. Riella M. Metabolismo del agua, del sodio, de potasio y del magnesio en la insuficiencia renal crónica. In: Riella, Miguel C. Martins C, editors. Nutrición y Riñón. 1 ${ }^{\circ}$ Edición. Río de Janeiro, Brasil: Editorial Medica Panamericana; 2001. p. 28-34.

35. Hruska KA, Sugatani T, Agapova O, Fang Y. The chronic kidney disease-mineral bone disorder (CKD-MBD): advances in pathophysiology. Bone. 2017;100:80-6.

36. Wheeler DC, Winkelmayer W. KDIGO 2017 Clinical practice guideline update for the diagnosis, evaluation, prevention, and treatment of chronic kidney disease-mineral and bone disorder (CKD-MBD). Vol. 7, Kidney international supplements. U.S.: Elsevier; 2017.

37. Karras Spyridon, Wagner CarolL, Castracane VD. Understanding vitamin $\mathrm{D}$ metabolism in pregnancy: from physiology to pathophysiology and clinical outcomes. Metab Clin Exp. 2018;86:112-23.

38. American College of Obstetricians and Gynecologists. Vitamin D: screening and supplementation during pregnancy. U.S.: American College of Obstetricians and Gynecologists; 2011.

39. Stallings VA, Harrison M, Oria M. Dietary Reference Intakes (DRIs): recommended dietary allowances and adequate intakes, vitamins food and nutrition board, institute of medicine, national academies. U.S.: Food and Nutrition Board; 2011.

40. WHO. Guidelines Approved by the Guidelines Review Committee. WHO recommendation: Calcium supplementation during pregnancy for the prevention of pre-eclampsia and its complications. Geneva: WHO; 2018.

41. Stover J. Pregnancy and chronic kidney disease. In: Byham-gray L, Stover J, Wiesen K, editors. A Clinical guide to nutrition in kidney disease. 2nd ed. Maywood, IL: American Dietetic Association; 2013. p. 151-6.

42. KDIGO Anemia Work Group. KDIGO clinical practice guideline for anaemia in chronic kidney disease 2012. Vol. 2, U.S.: International Society of Nephrology; 2012.

43. Mikhail A, Brown C, Williams JA, Mathrani V, Shrivastava R, Evans J, et al. Renal association clinical practice guideline on Anaemia of Chronic Kidney Disease. BMC Nephrol. 2017;18:345.

44. Sun D, McLeod A, Gandhi S, Malinowski AK, Shehata N. Anemia in pregnancy: a pragmatic approach. Obstetr Gynecol Surv. 2017;72:730-7.

45. WHO. Guideline Daily iron and folic acid supplementation in pregnant women III Contents. Geneva: WHO; 2012.

46. WHO. Guideline: daily iron and folic acid supplementation in pregnant women. Geneva: The WHO Reproductive Health Library; 2012. 